\title{
Supression of seed borne Cladosporium herbarum on common bean seed by Trichoderma harzianum and promotion of seedling development
}

\author{
Gesiane R. Guimarães ${ }^{1}$, Faber S. Pereira ${ }^{1}$, Fabio S. Matos $^{2}$, Sueli C. M. Mello ${ }^{3}$ \& Daniel D. C. Carvalho ${ }^{1}$ \\ ${ }^{1}$ Laboratório de Fitopatologia, Universidade Estadual de Goiás. Rodovia GO 330, km 241, Anel Viário, Setor Universitário, \\ 75780-000, Ipameri, GO, Brazil; ${ }^{2}$ Laboratório de Produção Vegetal, Universidade Estadual de Goiás, Rodovia GO 330, \\ km 241, Anel Viário, Setor Universitário, 75780-000, Ipameri, GO, Brazil; ${ }^{3}$ Embrapa Recursos Genéticos e Biotecnologia, \\ Parque Estação Biológica, Final W-5 Norte, Cx. Postal 02372, 70770-900, Brasília, DF, Brazil
}

Author for correspondence: Daniel D. C. Carvalho, e-mail: daniel.carvalho@ueg.br

\begin{abstract}
Trichoderma harzianum isolates have been broadly used for biocontrol of plant diseases caused by fungi. Cladosporium herbarum is a common saprophyte and seed borne fungus, which is easy to manipulate under controlled conditions. It was chosen as a model to test the effectivity of seed treatments with $T$. harzianum. Common bean seeds (cv. Pérola) contaminated with $C$. herbarum were treated with conidial suspension $(C S)$ and autoclaved filtrate $(A F)$ of five isolates of $T$. harzianum and subsequently submitted to health and germination tests. The proportion of normal seedlings formed, the length of roots, hypocotyls and leaves, and total plantlet length, total plantlet biomass, root mass ratio (RMR), stem mass ratio (SMR), leaf mass ratio (LMR), aerial part/root system ratio (AP/RS) and leaf area were also evaluated. Isolates CEN289 and CEN290 (CS and $A F$ ) provided 66 to 77\% of supression of $C$. herbarum on seeds and a higher number of normal seedlings as compared with control. It also yielded a higher total biomass of plantlets. Moreover treatment with isolates CEN289 and CEN290 increased root and stem length in the experiments with CS. Such results indicate the potential of T. harzianum for seed treatment and suggest that it should be further tested as control for seed borne fungal diseases and as a plant growth promoter. The better performance found for CEN289 and CEN290 confirms the variability in terms of biocontrol activity among strains of T. harzianum.
\end{abstract}

Key words: Phaseolus vulgaris, antagonism, biological control, seed pathology.

Common bean (Phaseolus vulgaris L.) is the most important source of protein for human nutrition in several countries, especially in Latin America and Africa. Brazil is the largest producer and consumer of this legume worldwide (Alwathnani et al., 2012). The incidence of pathogens in common bean seeds can reduce the physiological quality of the seeds, with consequences on the germination and initial stand establishment of the crops (Carvalho et al., 2014). Besides, seeds are important vehicles for the introduction and dissemination of pathogens into new areas. When seeds are exposed to inadequate moisture and temperatures during storage, growth of noxious fungi may result (Costa \& Scussel, 2002), resulting in loss of seed quality and viability. Cladosporium spp. are commonly found associated with seeds of crop and native plants (e.g. Dhingra et al., 2002) and Cladosporium herbarum (Pers.) Link is one of the most common species in this genus. Treatment of the seeds with fungicides can eliminate pathogens and protect seedlings against diseases and may be fundamental to produce an adequate plant stand and crop establishment (Carvalho et al., 2011). Although fungicides are used to control seed pathogens, the results are often not persistent (Salman \& Abuamsha, 2012). Moreover, the use of fungicides may have negative consequences to human health and the environment (Carvalho et al., 2007) and lead to the development of fungicide-resistant populations of plant pathogens (Maketon et al., 2008). Biological control of plant diseases with antagonists (alone or in combination with chemicals) is an important component of integrated plant disease management (Salman \& Abuamsha, 2012). Trichoderma species are widely used in agriculture as biopesticides, being efficient mycoparasites and prolific producers of secondary metabolites (Mukherjee et al., 2013). Seed treatment with Trichoderma spp. is an option that has been investigated as a substitute to chemical treatments and shown to have great potential (Carvalho et al., 2011; Maciel et al., 2014). Additionally, it is known that certain isolates of Trichoderma can form colonies on plant roots (HoyosCarvajal et al., 2009) and stimulate plant development by producing substances that promote plant growth and solubilize nutrients which may be assimilated by plants (Jha et al., 2013). In the present study selected isolates of Trichoderma harzianum Rifai were tested on common bean seeds for their effect on suppression of a common seedborne fungus $C$. herbarum and on early seedling growth promotion. 
Five T. harzianum isolates (CEN287, CEN288, CEN289, CEN290 and CEN316) belonging to the collection of fungi for biological control of plant pathogens of Embrapa Genetic Resources and Biotechnology (Brasília, DF, Brazil) selected in previous studies (Carvalho et al., 2011; Carvalho et al., 2014) were evaluated. The isolates had been previously identified on the basis of their morphological traits (Samuels et al., 2014) and sequencing of ITS-1 and ITS-4 regions of rDNA. The experiments were carried out at the Universidade Estadual de Goiás, Ipameri, State of Goiás, Brazil.

In order to produce inoculum, seven-day-old agar plugs $(5 \mathrm{~mm})$ of $T$. harzianum were transferred to $250 \mathrm{~mL}$ Erlenmeyer flasks (four plugs flask ${ }^{-1}$ ), containing parboiled rice $\left(15 \mathrm{~g} \mathrm{flask}^{-1}\right)$, previously moistened $\left(60 \% \mathrm{w} \mathrm{v}^{-1}\right)$ and autoclaved $\left(121^{\circ} \mathrm{C}\right.$ for $\left.40 \mathrm{~min}\right)$. After seeding flasks were kept at $25^{\circ} \mathrm{C}$ and $12 \mathrm{~h} / 12 \mathrm{~h}$ darkness/light. After six days, spores were collected by agitating colonized rice grains with distilled water and filtering through sterile cheesecloth. The conidial concentration for each T. harzianum isolate was adjusted at $2.5 \times 10^{8}$ conidia $\mathrm{mL}^{-1}$.

Metabolites of each T. harzianum isolate were also tested. These isolates were separately grown in $250 \mathrm{~mL}$ of potato dextrose broth (PDB) in $500 \mathrm{~mL}$ Erlenmeyer flasks at $120 \mathrm{rpm}$ on an orbital shaker (Quimis ${ }^{\circledR}$ Aparelhos Científicos Ltda., Q225K) at $25^{\circ} \mathrm{C}$ and $12 \mathrm{~h} / 12 \mathrm{~h}$ darkness/ light, for six days. After that period, filtrates of the five isolates were obtained and autoclaved at $121^{\circ} \mathrm{C}$ for $21 \mathrm{~min}$.

Common bean seeds (cv. Pérola) naturally contaminated externally with $C$. herbarum were treated with (a) $2 \mathrm{~mL}$ of a $2.5 \times 10^{8}$ conidia $\mathrm{mL}^{-1}$ suspension of $T$. harzianum per $100 \mathrm{~g}$ of seeds or (b) $2 \mathrm{~mL}$ of autoclaved filtrate of T. harzianum per $100 \mathrm{~g}$ of seeds. Subsequently a seed health test was performed through the blotter method, whereby 25 treated seeds were placed into a gerbox $(11 \mathrm{x}$ $11 \mathrm{~cm}$ ) containing two moistened paper blotter sheets. The gerbox were kept at $25^{\circ} \mathrm{C}$ with a light regime of 12 hours of light exposure, for seven days (light provided by a Philips daylight fluorescent lamp). After that, seeds were examined, individually, under a stereomicroscope. To confirm the presence of $C$. herbarum, semi-permanent microscope slides were prepared and examined under a Leica DM500 light microscope. The experiment was carried out in a completely randomized design, with eight replicates. Each replicate consisted of one gerbox containing 25 seeds. Seeds treated with carboxin+thiram $(300 \mathrm{~mL}$ per $100 \mathrm{~kg}$ of seeds; $200 \mathrm{~g}$ $\mathrm{L}^{-1}$ carboxin and $200 \mathrm{~g} \mathrm{~L}^{-1}$ thiram) and non-treated seeds were used as positive and negative controls, respectively. Autoclaved PDB medium was used as negative control in the test with $A F$.

A separate assay aimed at evaluating the effect of treatment with $C S$ and $A F$ of $T$. harzianum, on germination and early seedling development was performed. The same treatments and doses mentioned above were used, except for the fungicide treatment. After being treated, the seeds were subjected to the germination test, which was carried out in a randomized block design (RBD) with four replicates of 50 seeds per treatment. Seeds were placed on germitest rolls ( 50 seeds per roll), incubated in a germinator $\left(\right.$ Logen Scientific ${ }^{\circledR}$ ) at $25^{\circ} \mathrm{C}$, for nine days. After incubation, the following were evaluated: (a) percentage of abnormal seedlings (seedlings exhibiting necrosis along the roots, hypocotyls and cotyledons; seminal and secondary stunted and malformed roots, or absence of secondary roots), (b) percentage of normal seedlings (absence of necrosis and pathogen, seminal and secondary roots without deformations) and (c) percentage of dead seeds. All normal seedlings of each treatment were measured, separately, as follows: (a) root length, (b) hypocotyl length, (c) leaf length and $(\mathrm{d})$ total length $(\mathrm{a}+\mathrm{b}+\mathrm{c})$. Additionally, leaf area $\left(\mathrm{cm}^{2}\right)$ was calculated from leaf length and width data using the equation according to Figueiredo et al. (2012). Leaves, roots and stems were then detached and dried at $72^{\circ} \mathrm{C}$ until reaching a constant dry mass and the values (in grams) of root dry mass (rdm), stem dry mass (sdm) and leaf dry mass (ldm) were recorded. The total biomass $(\mathrm{rdm}+\mathrm{sdm}+\mathrm{ldm})$, the leaf mass ratio $[\mathrm{LMR}=(\mathrm{ldm}) /($ total biomass $)]$ and the aerial part/root system ratio $(\mathrm{AP} / \mathrm{RS})[\mathrm{AP} / \mathrm{RS}=(\mathrm{sdm}+\mathrm{ldm}) /$ $(\mathrm{rdm})]$ were then calculated.

The data were subjected to analysis of variance and to the Scott-Knott test $(\mathrm{P} \leq 0.05)$, using the SISVAR software (Ferreira, 2011).

The fungicide treatment was the most effective leading to complete eradication of $C$. herbarum from seeds (Table 1). Levels of control of C. herbarum on seeds reached with $C S$ treatments with $T$. harzianum varied between 67 and $77 \%$ for the five isolates of T. harzianum. For $A F$ treatments CEN289 and CEN290 had the best performance reaching a control higher than $70 \%$ (75 and $73 \%$, respectively). Additionally, isolates CEN289 and CEN290 yielded the highest number of normal seedlings for both $C S$ and $A F$ treatments, respectively, $62 \%$ and $36 \%$ more normal seedlings than control.

As for the length of seedlings, it was observed that the only $C S$ treatments which significantly increased root and hypocotyl length were those involving isolates CEN289 and CEN290 (Table 2). Total length of seedling was statistically superior for CEN287, CEN289 and CEN290 CS-treated seeds. Conversely, in $A F$-treated seeds no significant statistic distinction was found between treatments (Table 2). $C S$ and $A F$ application on seeds yielded significantly higher values for leaf length for isolates CEN287, CEN289 and CEN316 as compared with other isolates and control. As for total plantlet length only $C S$ applications had a statistically significant result and isolates, CEN287, CEN289 and CEN290 yielded higher values as compared to other isolates and control.

Root length values were higher in the $C S$ experiment for all isolates of $T$. harzianum as compared to $A F$. Total length values were higher in the $C S$ experiment for all isolates of T. harzianum, except for CEN316, compared to $A F$. 
Supression of seed borne Cladosporium herbarum on common bean seed by Trichoderma harzianum...

TABLE 1 - Incidence of Cladosporium herbarum on common bean seeds cv. Pérola treated with conidial suspension (CS) of Trichoderma harzianum and its autoclaved filtrate $(A F)$, and the respective effect of each treatment on normal seedling formation ${ }^{(1)}$.

\begin{tabular}{|c|c|c|c|c|}
\hline \multirow[t]{2}{*}{ Treatment } & \multicolumn{2}{|c|}{ Incidence (\%) } & \multicolumn{2}{|c|}{ Normal seedlings $^{(2)}$} \\
\hline & $C S$ & $A F$ & $C S$ & $A F$ \\
\hline CEN287 & $31.0 \mathrm{c}$ & $22.5 \mathrm{c}$ & $43.7 \mathrm{~b}$ & $42.7 \mathrm{a}$ \\
\hline CEN288 & $25.5 \mathrm{~b}$ & $27.0 \mathrm{c}$ & $42.0 \mathrm{~b}$ & $40.7 \mathrm{~b}$ \\
\hline CEN289 & $23.0 \mathrm{~b}$ & $14.5 \mathrm{~b}$ & $46.5 \mathrm{a}$ & $43.7 \mathrm{a}$ \\
\hline CEN290 & $22.5 \mathrm{~b}$ & $16.0 \mathrm{~b}$ & $46.0 \mathrm{a}$ & $43.7 \mathrm{a}$ \\
\hline CEN316 & $21.0 \mathrm{~b}$ & $26.5 \mathrm{c}$ & $41.2 \mathrm{~b}$ & $41.2 \mathrm{~b}$ \\
\hline Carboxin+thiram ${ }^{(3)}$ & $0 \mathrm{a}$ & $0 \mathrm{a}$ & - & - \\
\hline Control & $94.0 \mathrm{~d}$ & $59.5 \mathrm{~d}$ & $28.7 \mathrm{c}$ & $32.0 \mathrm{c}$ \\
\hline $\mathrm{PDB}^{(4)}$ & - & $73.0 \mathrm{e}$ & - & $33.0 \mathrm{c}$ \\
\hline $\mathrm{CV}(\%)$ & 20.14 & 22.49 & 4.02 & 3.28 \\
\hline
\end{tabular}

${ }^{(1)}$ Means followed by the same letter within the same column do not differ by Scott Knott test $(\mathrm{P} \leq 0.05)$.

${ }^{(2)}$ Seedlings originated from seeds naturally contaminated by $C$. herbarum.

${ }^{(3)}$ Carboxin+thiram (300 mL $100 \mathrm{~kg}^{-1}$ of seeds; $200 \mathrm{~g} \mathrm{~L}^{-1}$ carboxin and $200 \mathrm{~g} \mathrm{~L}^{-1}$ thiram)

${ }^{(4)}$ Potato dextrose broth (200 $\mathrm{g}$ cooked potato, $20 \mathrm{~g}$ dextrose, $1000 \mathrm{~mL}$ distilled water).

TABLE 2 - Root length $(\mathrm{cm})$, hypocotyl length, leaf length and total length of common bean seedlings cv. Pérola originated from seeds treated with conidial suspension $(C S)$ of $T$. harzianum and its autoclaved filtrate $(A F)^{(1)}$.

\begin{tabular}{|c|c|c|c|c|c|c|c|c|}
\hline \multirow[t]{2}{*}{ Treatment } & \multicolumn{2}{|c|}{ Root length } & \multicolumn{2}{|c|}{ Hypocotyl length } & \multicolumn{2}{|c|}{ Leave length } & \multicolumn{2}{|c|}{ Total length } \\
\hline & $C S$ & $A F$ & $C S$ & $A F$ & $C S$ & $A F$ & $C S$ & $A F$ \\
\hline CEN287 & $11.76 \mathrm{bA}$ & $9.89 \mathrm{aB}$ & $7.94 \mathrm{bA}$ & $6.93^{\text {ns }} A$ & $1.63 \mathrm{aA}$ & $1.43 \mathrm{aA}$ & $21.33 \mathrm{aA}$ & $18.25^{\text {ns }} B$ \\
\hline CEN288 & $11.22 \mathrm{bA}$ & $7.37 \mathrm{bB}$ & $7.38 \mathrm{bA}$ & $5.85 \mathrm{~A}$ & $1.41 \mathrm{bA}$ & $1.41 \mathrm{aA}$ & $20.02 \mathrm{bA}$ & $14.63 \mathrm{~B}$ \\
\hline CEN289 & $12.57 \mathrm{aA}$ & $9.59 \mathrm{aB}$ & $9.10 \mathrm{aA}$ & $7.56 \mathrm{~A}$ & $1.56 \mathrm{aA}$ & $1.45 \mathrm{aA}$ & $23.98 \mathrm{aA}$ & $18.60 \mathrm{~B}$ \\
\hline CEN290 & $13.31 \mathrm{aA}$ & $8.71 \mathrm{aB}$ & $8.77 \mathrm{aA}$ & $6.33 \mathrm{~B}$ & $1.43 \mathrm{bA}$ & $1.23 \mathrm{bA}$ & $22.78 \mathrm{aA}$ & $16.27 \mathrm{~B}$ \\
\hline CEN316 & $11.27 \mathrm{bA}$ & $9.57 \mathrm{aB}$ & $7.41 \mathrm{bA}$ & $7.04 \mathrm{~A}$ & $1.60 \mathrm{aA}$ & $1.62 \mathrm{aA}$ & $20.29 \mathrm{bA}$ & $18.23 \mathrm{~A}$ \\
\hline Control & $8.94 \mathrm{cA}$ & $7.99 \mathrm{bA}$ & $7.05 \mathrm{bA}$ & $5.68 \mathrm{~A}$ & $1.12 \mathrm{cA}$ & $1.09 \mathrm{bA}$ & $17.14 \mathrm{cA}$ & $14.76 \mathrm{~A}$ \\
\hline $\mathrm{PDB}^{(2)}$ & - & $7.68 \mathrm{~b}$ & - & 7,68 & - & $1.15 \mathrm{~b}$ & - & 16.51 \\
\hline $\mathrm{CV}(\%)$ & 7.30 & 14.11 & 12.82 & 21.98 & 8.63 & 14.27 & 8.39 & 16.78 \\
\hline
\end{tabular}

${ }^{(1)}$ Means followed by the same small letter within the same column and the same capital letter in the same line do not differ by Scott Knott test $(\mathrm{P} \leq 0.05)$.

(2) Potato dextrose broth (200 $\mathrm{g}$ cooked potato, $20 \mathrm{~g}$ dextrose, $1000 \mathrm{~mL}$ distilled water).

${ }^{n s}$ Not significant.

CS applications on seeds of CEN289 and CEN290 resulted in the highest values of total biomass (Table 3). $A F$ applications yielded a total biomass of $133.43 \mathrm{~g}$ for CEN289, $128.13 \mathrm{~g}$ for CEN290 and $70.39 \mathrm{~g}$ for control, respectively.

Values of root-mass ratio for seeds treated with isolates of T. harzianum (0.07-0.16) were lower than those of the control for $C S(0.31)$ and $A F(0.28)$ treatments. On the other hand, values of stem mass ratio of the seedlings for seed treated with $C S$ and $A F$ (0.8-0.89) were higher than those of control.

Treatments involving most isolates of T. harzianum (either $C S$ or $A F$ ) yielded lower values of leaf mass ratio as compared to control. The sole exception was CEN287. The aerial part/root system ratio (9.02-13.42) of seedlings resulting from $C S$ and $A F$ treated seeds was higher than that of control. The leaf area of the seedlings produced from $C S$ and $A F$-treated seeds was higher than that observed for control for isolates CEN287, CEN289 and CEN316. No differences were observed between $C S$ or $A F$ treatment for the development variables under evaluation (Table 3).

According to Barbosa et al. (2001), the antagonistic action of Trichoderma spp. against $C$. herbarum happens through direct mycoparasitism, including the sporulation of the antagonist within the pathogen's hyphae. Moreover, possible explanation for the effect of $A F$ may be: (1) antibiotic production by Trichoderma such as trichodermin, trichodermol, harzianum A and harzianolid; (2) fungal cell wall-degrading enzymes, such as lipase, NAGase, $\beta-1,3-$ glucanase, $\beta$-glucosidase and protease which are noxious to hyphae of various plant pathogens (Dickinson et al., 1995; Geraldine et al., 2013).

Carvalho et al. (2011) also reported that carboxin+thiram completely eradicated Cladosporium sp. in common bean seeds. These authors found that the biological treatment (isolates of T. harzianum: CEN287, CEN288, CEN289, CEB290 and CEN316) reduced the fungus incidence in seeds at 14 to $41 \%$. In the present study, the 
G.R. Guimarães et al.

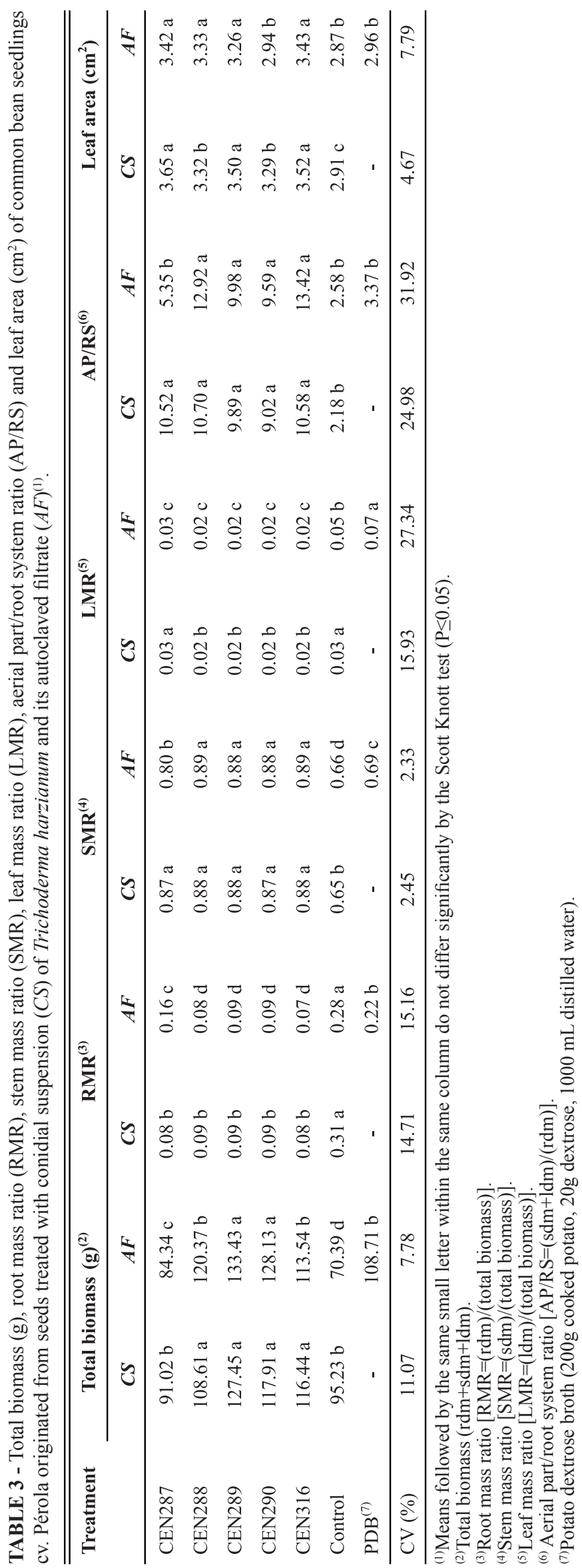


reduction rates of $C$. herbarum incidence in contaminated seeds were higher than those reported by Carvalho et al (2011). Reduction rates ranged from 67 to $77 \%$ for $C S$ and from 54 to $75 \%$ to $A F$. Since the antagonist isolates involved in those two studies were different, the performance differences were possibly due to variations in the $C$. herbarum population involved which were those naturally occurring on the seeds in both cases (Narayanasamy, 2011). Curiously, the isolates CEN289 and CEN290 differed from the others in terms of percentage of normal seedlings in both $C S$ and $A F$ treatments. The coincidence of this result with those obtained in the evaluation of the incidence of $C$. herbarum on seeds, when $A F$ was used, suggests that metabolites produced by these two isolates play some role in yielding high rates of normal seedlings. In the specific case, those metabolites were applied directly ( $A F$ experiment) and indirectly ( $C S$ experiment), resulting in similar rates of normal seedlings.

According to Saito et al. (2011), the factors involved in the promotion of plant development by Trichoderma species are still poorly understood. When $C S$ or $A F$ treatments were compared (Table 2), it was found that, for all isolates, root length values were higher for $C S$ treatments than for $A F$ treatments. This suggests that thermolabile substances produced by $T$. harzianum such as hormones and vitamins and other plant growth-stimulating substances, only available for $C S$-treated seeds and resulting plantlets may be involved. In other words, active fractions present in the metabolites produced in PDB may have been decomposed into inactive fractions after autoclaving of the metabolites. Thus, the increase in the root length follows an increase in the total length in crops treated with Trichoderma spp. (Saito et al., 2011; Carvalho et al., 2011). According to Harman (2000) Trichoderma harzianum is favored by the presence of abundant root systems which it can easily colonize. Some isolates are highly capable of colonizing and growing in roots just following their development. Isolates of T. harzianum which have good performance at colonizing roots may be added to the soil or to seeds and after coming into contact with the roots, they colonize the root surface and/or the cortex, showing rhizocompetence, as demonstrated for the isolates CEN287, CEN288, CEN289, CEN290 and CEN316 by Carvalho et al. (2011).

Surprisingly the short period of exposure of the seedlings to $C S$ and $A F$ of $T$. harzianum was enough to trigger significant alterations in the leaves and, in particular, in the total biomass of the common bean seedlings. Thus, development analysis is an efficient tool for identifying promising materials, besides identifying traits that, in the initial development, may promote increased yields in mature plants (Peixoto et al., 2006). The seedlings treated with $C S$ and $A F$ of $T$. harzianum showed high biomass accumulation and higher development of the aerial part, especially the stem. Total biomass is an important variable to select promising isolates to be applied under field conditions (Nobre et al., 2011; Matos et al., 2012). Thus, the higher biomass accumulation in seedlings treated with CEN289 was in line with higher photosynthesizing leaf area.

Carvalho et al. (2011) conducted experiments with the same isolates of T. harzianum in common bean plants $\mathrm{cv}$. 'Jalo Precoce' under greenhouse and field conditions; they found that CEN289 and CEN290 promoted increased root length as compared with control. On the contrary, reduced biomass allocation in the root system of plants treated with $C S$ and $A F$ of $T$. harzianum was interpreted as resulting from high water availability for the seedlings which were irrigated daily during the germination test. Thus, without water restriction, the allocation of resources to root system formation was not justified. Consequently, the high AP/RS ratio of the seedlings treated with $C S$ and $A F$ of $T$. harzianum was likely to result from strong allocation of resources to the formation of aerial part tissues.

As a conclusion to this study, it can be said that the treatment of seeds of common bean cv. Pérola with $C S$ and $A F$ of $T$. harzianum can reduce the population of the model seed-borne fungus $C$. herbarum, and improve the development of seedlings. Root growth promotion was only possible by using $C S$. Seedlings from seeds treated with the isolates of $T$. harzianum (either through $C S$ or $A F$ seed treatment), especially with CEN289 and CEN290, showed high biomass accumulation and vigorous vegetative development.

\section{ACKNOWLEDGEMENTS}

The authors express their thanks to the Coordenação de Aperfeiçoamento de Pessoal de Nível Superior - CAPES for providing a fellowship to G. R. Guimarães, the Fundação de Amparo à Pesquisa do Estado de Goiás - FAPEG for providing financial support for the research (Proc. 201310267001026) and to Embrapa Genetic Resources and Biotechnology for loan of the isolates of Trichoderma harzianum (TRTM 02/2012), and the Universidade Estadual de Goiás - UEG.

\section{REFERENCES}

Alwathnani HA, Perveen K, Tahmaz R, Alhaqbani S (2012) Evaluation of biological control potential of locally isolated antagonist fungi against Fusarium oxysporum under in vitro and pot conditions. African Journal of Microbiology Research 6:312319.

Barbosa MAG, Rehn KG, Menezes M, Mariano RLR (2001) Antagonism of Trichoderma species on Cladosporium herbarum and their enzimatic characterization. Brazilian Journal of Microbiology 32:98-104.

Carvalho DDC, Lobo Junior M, Martins I, Inglis PW, Mello SCM (2014) Biological control of Fusarium oxysporum f. sp. phaseoli by Trichoderma harzianum and its use for common bean seed treatment. Tropical Plant Pathology 39:384-391.

Carvalho DDC, Mello SCM, Lobo Junior M, Geraldine AM (2011) Biocontrol of seed pathogens and growth promotion of common 
bean seedlings by Trichoderma harzianum. Pesquisa Agropecuária Brasileira 46:822-828.

Carvalho DDC, Oliveira DF, Corrêa RSB, Campos VP, Guimarães RM, Coimbra JL (2007) Rhizobacteria able to produce phytotoxic metabolites. Brazilian Journal of Microbiology 38:759-765.

Costa LLF, Scussel VM(2002) Toxigenic fungi in beans (Phaseolus vulgaris $\mathrm{L}$.) classes black and color cultivated in the state of Santa Catarina, Brazil. Brazilian Journal of Microbiology 33:138-144.

Dhingra OD, Maia CB, Lustosa DC, Mesquita JB (2002) Seed borne pathogenic fungi that affect seedling quality of red angico (Anadenanthera macrocarpa) trees in Brazil. Journal of Phytopatology 150:451-455.

Dickinson JM, Hanson JR, Truneh A (1995) Metabolites of some biological control agents. Pesticide Science 44:389-393.

Ferreira DF (2011) Sisvar: a computer statistical analysis system. Ciência e Agrotecnologia 35: 1039-1042.

Figueiredo ES, Santos ME, Garcia A (2012) Modelos de determinação não destrutivo da área foliar do feijoeiro comum Phaseolus vulgaris L. Nucleus 9:79-84.

Geraldine AM, Lopes FAC, Carvalho DDC, Barbosa ET, Rodrigues AR, Brandão RS, Ulhoa CJ, Lobo Junior M (2013) Cell wall-degrading enzymes and parasitism of sclerotia are key factors on field biocontrol of white mold by Trichoderma spp. Biological Control 67:308-316.

Harman GE (2000) Myths and dogmas of biocontrol: changes in perceptions derived from research on Trichoderma harzianum T-22. Plant Disease 84:377-393.

Hoyos-Carvajal L, Orduz S, Bissett J (2009) Growth stimulation in bean (Phaseolus vulgaris L.) by Trichoderma. Biological Control 51:409-416.

Jha PN, Gupta G, Jha P, Mehrotra R (2013) Association of rhizospheric/endophytic bacteria with plants: a potential gateway to sustainable agriculture. Greener Journal of Agricultural Sciences 3:073-084.

Maciel CG, Walker C, Muniz MFB, Araújo MM (2014)
Antagonismo de Trichoderma spp. e Bacillus subtilis (UFV3918) a Fusarium sambucinum em Pinus elliottii Engelm. Revista Árvore 38:505-512.

Maketon M, Apisitsantikul J, Siriraweekul C (2008) Greenhouse evaluation of Bacillus subtilis AP-01 and Trichoderma harzianum AP-001 in controlling tobacco diseases. Brazilian Journal of Microbiology 39:296-300.

Matos FS, Gamboa I, Ribeiro RP, Mayer ML, Neves TG, Leonardo BRL, Souza AC (2012) Influência da intensidade luminosa no desenvolvimento de mudas de Jatropha curcas L. Agrarian 4:265272.

Mukherjee PK, Horwitz BA, Herrera-Estrella A, Schmoll M, Kenerley CM (2013) Trichoderma research in the genome era. Annual Review of Phytopathology 51:105-129.

Narayanasamy P (2011) Microbial plant pathogens-detection and disease diagnosis: Fungal pathogens. v.1. Berlin. Springer.

Nobre RG, Gheyi HG, Soares FAL, Cardoso JAF (2011) Produção de girassol sob estresse salino e adubação nitrogenada. Revista Brasileira de Ciências do Solo 35:929-937.

Peixoto CP, Cerqueira EC, Soares Filho WS, Castro Neto MT, Ledo CAS, Matos FS, Oliveira JG (2006) Análise de crescimento de diferentes genótipos de citros cultivados sob déficit hídrico. Revista Brasileira de Fruticultura 28:439-443.

Saito LR, Sales LLDR, Martinckoski L, Royer R, Ramos MS, Reffatti T (2011) Aspectos dos efeitos do fungo Trichoderma spp. no biocontrole de patógenos de culturas agrícolas. Revista Brasileira de Tecnologia Aplicada nas Ciências Agrárias 2:203208.

Salman M, Abuamsha R (2012) Potential for integrated biological and chemical control of damping-off disease caused by Pythium ultimum in tomato. Biological Control 57:711-718.

Samuels GJ, Chaverri P, Farr DF, McCray EB (2014) Trichoderma online, Systematic Mycology and Microbiology Laboratory, ARS, USDA. Available at: <http://nt.ars-grin.gov/taxadescriptions/keys/ Trichoderma Index.cfm>. Accessed on May 19, 2014.

TPP-2014-0070

Submitted: 20 May 2014

Revisions requested: 22 June 2014

Accepted: 15 July 2014

Section Editor: Trazilbo José de Paula Junior 